\title{
Soluble Guanylate Cyclase Inhibitors Discovered among Natural Compounds
}

Olga N. Petrova, Isabelle Lamarre, Fabienne Fasani, Catherine Grillon and Michel Negrerie

Corresponding author:

michel.negrerie@polytechnique.edu

ABSTRACT: Soluble guanylate cyclase (sGC) is the human receptor of nitric oxide (NO) in numerous kinds of cells and produces the second messenger cGMP upon NO binding to its heme. sGC is involved in many cell signaling pathways both in healthy conditions and in pathological conditions, such as angiogenesis associated with tumor growth. Addressing the selective inhibition of the NO/cGMP pathway is a strategy worthwhile to be investigated for slowing down tumoral angiogenesis or for curing vasoplegia. However sGC inhibitors are lacking to investigation. We have explored a chemical library of various natural compounds and have discovered inhibitors of sGC. The selected compounds were evaluated for their inhibition of purified sGC in vitro and sGC in endothelial cells. Six natural compounds, from various organisms, have $I C_{50}$ in the range $0.2-1.5 \mu \mathrm{M}$ for inhibiting the NO-activated synthesis of cGMP by sGC and selected compounds exhibit a quantified anti-angiogenic activity using an endothelial cell line. These sGC inhibitors can be used directly as tools to investigate angiogenesis and cell signaling, or as templates for drug design.

\section{Table of Contents/Abstract Graphic}
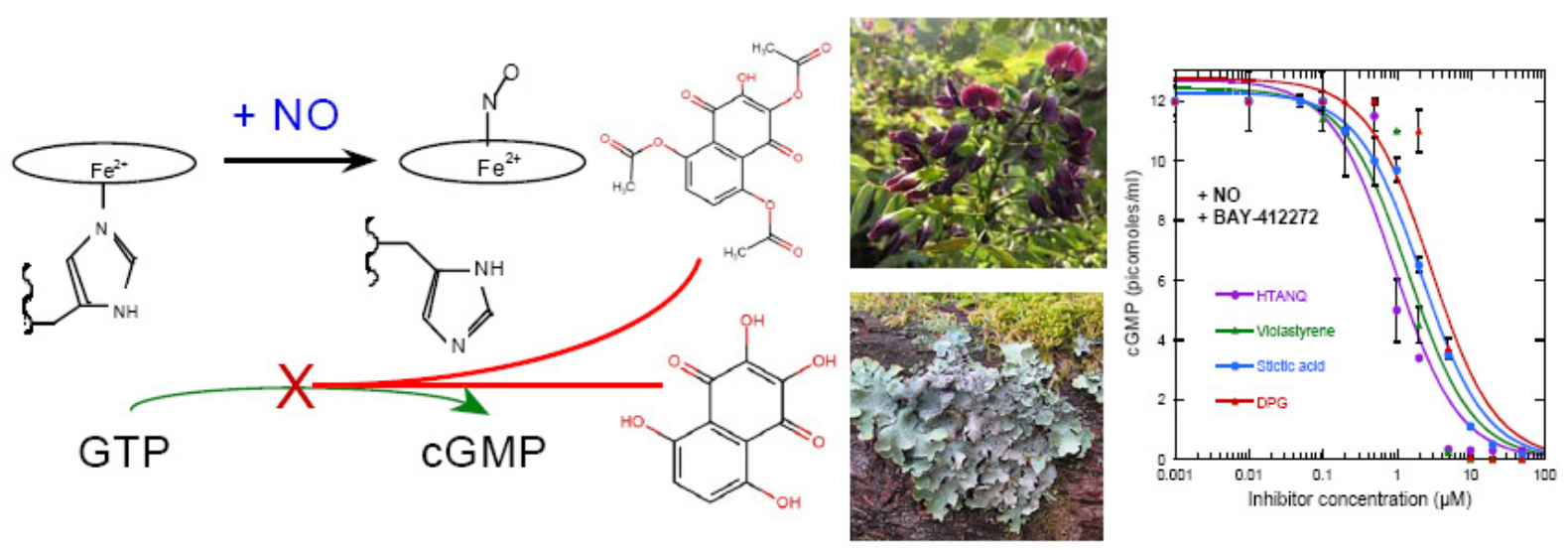
Soluble guanylate cyclase (sGC), the human receptor of nitric oxide (NO), ${ }^{1-3}$ catalyzes the formation of the second messenger cGMP from GTP after activation by the binding of NO to its heme. sGC is located in many organs (such as heart, lung, kidney, intestine endothelium, aortic endothelium) and the $\mathrm{NO} / \mathrm{sGC} / \mathrm{cGMP}$ signaling pathway is involved in a wide variety of regulation processes, including: regulation of blood pressure through vasodilation, ${ }^{4,5}$ immune response, ${ }^{6}$ platelet aggregation, ${ }^{7}$ communication between neurons ${ }^{8}$ and lipolysis. ${ }^{9}$ sGC also controls processes which determine the cell fate: proliferation and differentiation of cells, ${ }^{10}$ apoptosis, ${ }^{11}$ signaling in angiogenesis linked to tumor cell proliferation. ${ }^{12}$ The selective inhibition or activation of the $\mathrm{NO} / \mathrm{sGC} / \mathrm{cGMP}$ pathway has major effects and therefore constitutes pathological and therapeutic issues. ${ }^{13-15}$ For curing cardiovascular diseases, in particular pulmonary hypertension, sGC activators were developed in the last two decades, ${ }^{14,16}$ based on the molecule $\mathrm{YC}-1^{17}$ as a template, the very first compound discovered which is active on this allosteric ${ }^{18}$ enzyme. The two subunits of sGC each possess a catalytic domain and a H-NOX domain ${ }^{19}$ and the NO-independent activators bind to an allosteric site located in the $\beta 1 \mathrm{H}-\mathrm{NOX}$ sensing domain ${ }^{20,21}$ which also harbours the unique heme.

The NO-cGMP pathway exhibits a paradoxical role in cancer since it is involved in several physiological processes. First, the differential expression of the sGC subunits (together with NOS-1 and PKG) has been evidenced in various human cancer models compared with respective normal tissues. ${ }^{22-25}$ Subunits sGC $\alpha 1$ and sGC $\beta 1$ are less expressed in brain, lung and breast cancers, but sGC $\alpha 1$ is more expressed in prostate and ovarian cancers, while sGC $\beta 1$ is increased in lymphoma, ovarian and head cancers. ${ }^{24}$ Over-expression of $\mathrm{sGC} \alpha 1$ and $\mathrm{sGC} \beta 1$ in particular breast cancer cells suppressed cell proliferation, induced apoptosis and reduced tumor volume and growth in mice with tumor cells xenografts. ${ }^{25}$ In this case, the activation of NO-cGMP signaling pathway by targetting sGC and PDE was shown to inhibit the growth of various cancer cell lines. In human glioma tissues, the restoration of sGC expression, genetically or pharmacologically, significantly inhibited glioma growth. ${ }^{24}$

Secondly, activation of sGC is also involved in resistance to apoptosis in melanoma, ${ }^{26}$ ovarian, ${ }^{27}$ prostate $^{28}$ and other types of tumor cells. ${ }^{29,30}$ In particular, NO/sGC/cGMP signaling mediates angiogenesis linked to tumor growth $^{31}$ in endothelial cells ${ }^{32}$ and the inhibition of sGC blocks the neovascularization and vessels growth, ${ }^{33}$ whereas its activation promotes endothelial cells proliferation. Furthermore, inhibitors of endothelial NO-synthase induce the decrease of number and length of newly formed vessels in endothelial cell lines. $^{34,35}$ Activation of sGC by NO activates the kinase PKG-I $\alpha$ which prevents spontaneous apoptosis and promotes proliferation of many types of cells. ${ }^{11,27,36}$ Whether slowing down 
tumor progression by targetting the NO-cGMP pathway must involve its activation or its inhibition strongly depends on the target: diretcly tumor cells or endothelial cells to stop associated angiogenesis. For slowing down tumoral angiogenesis, the selective inhibition of the NO/cGMP pathway constitutes a possible strategy.

Beside cancer and apoptosis, sGC is also involved in other pathological states such as vasoplegia $^{37}$ and Parkinson's disease, ${ }^{38}$ pathologies which can gain benefits from sGC inhibitors. Attempts to control the pathological states described above could be performed by targeting sGC, but no efficient allosteric inhibitor exits so far. The most used inhibitors of sGC are ODQ (1-H(1,2,4)oxadiazolo(4,3-a)quinoxalin-1-one $)^{39,40}$ and its analogue NS-2028 $8^{41}$ which are non-competitive. They oxidize the heme and irreversibly damage the enzyme, are non specific and also target NO-synthase. ${ }^{42}$ Calmidazolium $^{43}$ and an artificial compound ${ }^{44}$ were reported to inhibit full-length $\mathrm{SGC}$ in vitro but with a rather high $I C_{50}$, in the range $10-$ $30 \mu \mathrm{M}$.

Here, we aimed at discovering sGC inhibitors by screening a library of very diverse natural compounds. We also evaluated the inhibition of $\mathrm{sGC}$ by hypericin, a naphthodianthrone pigment from the plant Hypericium perforatum (St John's Wort). We have previously shown that hypericin decreases cellular cGMP level in cardiomyocytes ${ }^{45}$ and assigned its activity to sGC inhibition, but it was never assayed in vitro on purified sGC so far. All selected compounds were evaluated for their inhibition of sGC both in vitro and in cells (HUVEC) and four tested compounds exhibit a quantified anti-angiogenic activity using an endothelial cell line. They could either be used directly as tools or serve as templates for drug design, as discussed below.

\section{RESULTS}

Searching sGC Inhibitors Among Natural Compounds. We have first screened a library containing 320 natural compounds extracted from plants and fungi which was chosen because of its broad diversity of chemicals (alkaloids, polyphenols, terpenoids and macrocycles). All compounds were first tested at a concentration of $20 \mu \mathrm{M}$ by measuring the cGMP production from GTP in the presence of the NO-donor nitroprusside (Supporting Figure S1). From this initial screening we found six compounds which fully inhibited purified sGC at $20 \mu \mathrm{M}$. This number of hits was favored by the chemical diversity of preselected compounds in the library. We did not find any compound which increases cGMP production in these conditions, in extenso, which activates sGC in synergy with NO. These compounds 
from various organisms are listed in Table 1 and depicted in Figure 1, together with hypericin (1) and hypocrellin A (2).

All compounds contain aromatic rings and hydroxyl groups. Stictic acid (3) is extracted from the antarctic lichen ${ }^{46}$ Parmeliaceae Parmelia and violastyrene (4), a dimethoxy derivative, comes from heartwood of Fabaceae Dalbergia miscolobium. Compounds $\mathbf{5}$ and $\mathbf{6}$ are extracted respectively from Pseudomonas putida and from the skin of Polyporaceae Fomes fomentarius. Compounds $\mathbf{7}$ and $\mathbf{8}$ are 2,3,5,8-tetrahydroxy-1,4-naphthoquinone derivatives from sea urchins. $^{47} \mathbf{6}$ and 8 contain halogene substituents $(\mathrm{Br}$ and $\mathrm{Cl})$. Furthermore, we found analogues of 4 which also partly inhibit sGC (Supporting Figure S2, compounds 9 - 14), and contain more hydroxyl and acetyl groups than 4 (Supporting Figure S3) whose position with respect to aromatic rings modulate the inhibitory effect.

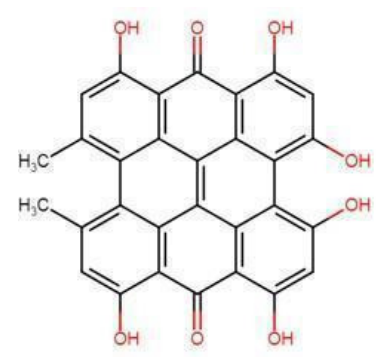

1

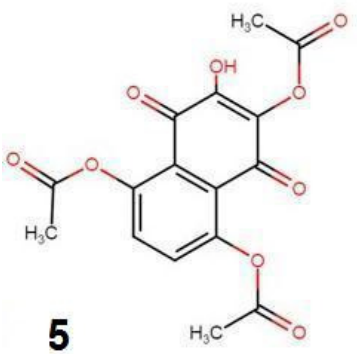

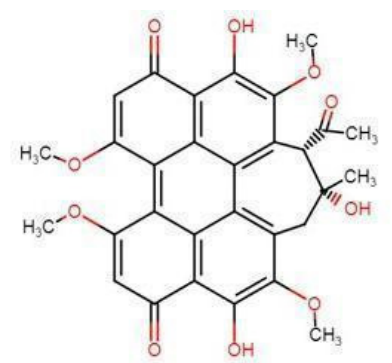

2

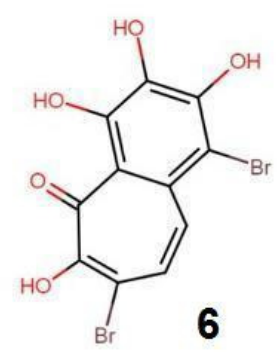

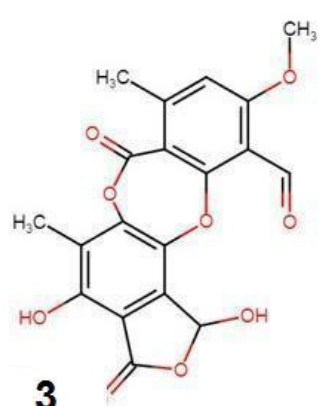

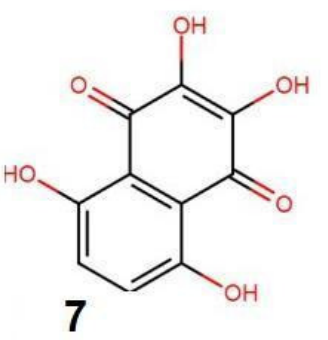

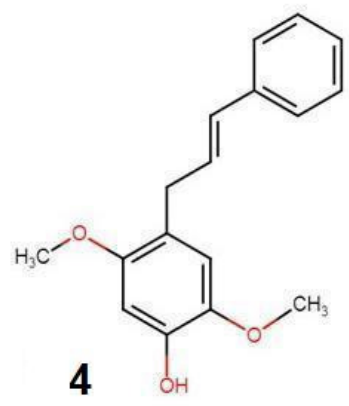

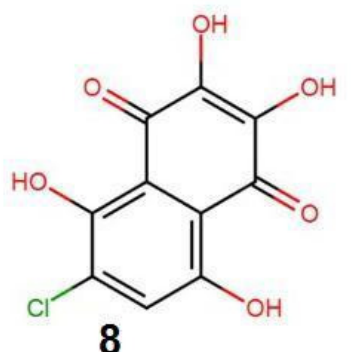

Figure 1. Structure of the discovered sGC inhibitors. (1) hypericin. (2) hypocrellin A. (3) stictic acid. (4) violastyrene [2,5-dimethoxy-4-(3-phenylpropenyl)phenol], (5) 2-hydroxy-3,5,8-triaceto-1,4naphthoquinone (HTANQ). (6) 3,6-dibromo-purpurogallin (DBPG), (7). 2,3,5,8tetrahydroxynaphthalene-1,4-dione (spinazarin; Ambinter 537501). (8) 6-chloro-2,3,5,8tetrahydroxynaphthalene-1,4-dione (chloro-spinazarin; Ambinter 537686).

Effect of Selected Compounds on Purified sGC Activity and in Endothelial Cells. We measured the inhibition constants $\left(I C_{50}\right)$ of compounds $\mathbf{1}-\mathbf{8}$ in the presence of NO, the natural activator of sGC. The catalytic activity was measured by immunoenzymatic assay both in vitro with purified protein and in vivo on cultured HUVEC cells. Purified sGC could be fully inhibited by the eight compounds (Figure 2 and Table 1) with constants $I C_{50}$ in the 
range $0.2-1.5 \mu \mathrm{M}$ for compounds $\mathbf{1}$ to $\mathbf{6}$ whereas the two naphtoquinone derivatives 7 and $\mathbf{8}$ disclose a slightly larger $I C_{50}(3-5 \mu \mathrm{M})$.
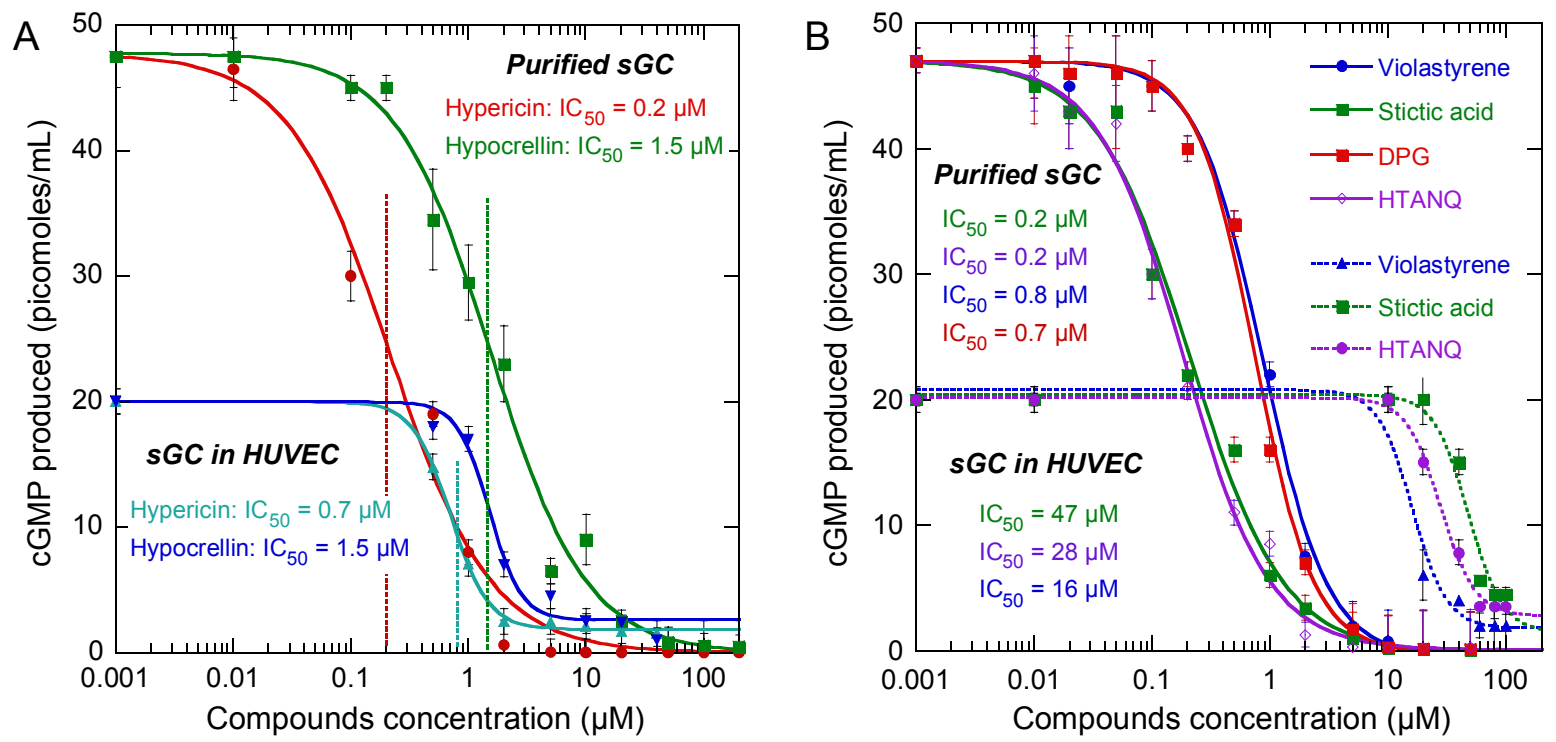

Figure 2. Inhibition of purified sGC and sGC in HUVEC by the natural compounds $\mathbf{1}$ and $\mathbf{2}$ (A) and $\mathbf{3}$ -6 (B). The curves were normalized to sGC activity in the absence of inhibitor, which was measured independently for each curve. For HUVEC measurements, the curves were normalized to the density of cells $\left(5.6 \times 10^{5}\right.$ cells $\left./ \mathrm{mL}\right)$. The amount of synthesized cGMP was measured in the presence of the NOdonor nitroprusside $(300 \mu \mathrm{M})$. Full activity is not the same for purified sGC and in HUVEC due to different sGC concentrations. Note that for HUVEC the baseline at high inhibitor concentration is not zero because the cells already contain cGMP produced during their growth. For concentration $>1 \mu \mathrm{M}$, $p \leq 0.001$.

In the case of HUVEC the assay curves did not reach the zero baseline as the concentration of compounds is increased, demonstrating that their cytosol contains internal cGMP prior to activation of sGC during the assay. Comparing purified sGC and HUVEC, the $I C_{50}$ evolved differently among inhibitors. Compounds $\mathbf{1}$ and $\mathbf{2}$ have similar inhibition constants $\left(I C_{50}=0.7 \mu \mathrm{M}\right.$ and $\left.I C_{50}=1.5 \mu \mathrm{M}\right)$ in HUVEC and with purified sGC (Figure $2 \mathrm{~A}$ and Table 1). This similarity is readily explained by the ability of compounds $\mathbf{1}$ and $\mathbf{2}$ to easily insert into the cell membrane due to both hydrophobic and hydrophilic hydroxylated groups. Although 1 and $\mathbf{2}$ may accumulate in cytoplasmic membranes such as the endoplasmic reticulum $^{48}$ and in mitochondria, ${ }^{49}$ they can easily reach sGC located in cytosol of endothelial cells. Indeed, the action of hypericin derivatives is coupled with their liposolubility. ${ }^{48}$ Contrarily, 3 - $\mathbf{6}$ required a larger concentration for sGC inhibition in cells (Table 1) due to lower ability to pass through the cell membrane. One must note that the concentration of inhibitors is certainly not the same in the cytosol as that initially put in the growth medium 
and is necessarily lower. Compound 6 did not have effect on HUVEC sGC up to $100 \mu \mathrm{M}$. The most plausible reason is a sequestration or adsorption of $\mathbf{6}$ on the cell membrane, precluding its diffusion into the cytosol. Possibly, the presence of two $\mathrm{Br}$ atoms in $\mathbf{6}$ precludes its insertion through the cell membrane.

Table 1. Inhibition constants for NO-activated sGC and origin of natural compounds.

\begin{tabular}{|c|c|c|c|c|c|}
\hline \multirow{2}{*}{ Compound } & \multicolumn{2}{|c|}{ IC $\boldsymbol{5 0}(\boldsymbol{\mu M})$} & \multicolumn{2}{c|}{ Organism } \\
\cline { 3 - 4 } & & Purified sGC & HUVEC & \multicolumn{2}{c|}{} \\
\hline $\mathbf{1}$ & Hypericin & $0.2 \pm 0.03$ & $0.7 \pm 0.05$ & Plant & Hypericium perforatum \\
\hline $\mathbf{2}$ & Hypocrellin A & $1.5 \pm 0.20$ & $1.5 \pm 0.1$ & Fungus & Hypocrella bambuase \\
\hline $\mathbf{3}$ & Stictic acid & $0.2 \pm 0.05$ & $47 \pm 5$ & Lichen & Parmeliaceae Parmelia \\
\hline $\mathbf{4}$ & Violastyrene & $0.8 \pm 0.05$ & $16 \pm 3$ & Plant & Dalbergia miscolobium \\
\hline $\mathbf{5}$ & HTANQ & $0.2 \pm 0.05$ & $28 \pm 2$ & Bacteria & Pseudomonas putida \\
\hline $\mathbf{6}$ & DBPG & $0.7 \pm 0.04$ & $>200$ & Fungus & Fomes fomentariu \\
\hline $\mathbf{7}$ & Spinazarin & $5 \pm 0.5$ & $10 \pm 2$ & Echinodermata & Scaphechinus mirabilis \\
\hline $\mathbf{8}$ & Chloro-spinazarin & $3 \pm 0.5$ & $13 \pm 2$ & Echinodermata & Sea urchins \\
\hline
\end{tabular}

For HUVEC the concentration is that put in the growth medium, not that in the cytosol.

We have further identified two compounds whose structures are based on naphtalene and were selected from their similarity with 5 (Figure 1). Compounds 7 and 8 possess hydroxyls replacing the ester groups present in $\mathbf{5}$ to which their inhibitory action on purified sGC and in HUVEC was compared (Figure 3). Compounds 7 and $\mathbf{8}$ inhibit sGC with half maximal concentrations $I C_{50}(7)=5 \mu \mathrm{M}$ and $I C_{50}(\mathbf{8})=3 \mu \mathrm{M}$ higher than that of $5(0.2 \mu \mathrm{M})$ on purified sGC. However they appeared more efficient than $\mathbf{5}$ in HUVEC cells with $I C_{50}=10,13$ and 28 $\mu \mathrm{M}$ respectively (Figure 3B and Table 1). We assigned the more efficient sGC inhibition in HUVEC by $\mathbf{7}$ and $\mathbf{8}$ compared to $\mathbf{5}$ to their better ability to insert through the cell membrane due to the absence of ester groups which are replaced with hydroxyls. Altenatively, cellular esterases could cleave the ester groups of 5 whose structure then becomes similar to that of 7 , which is has a lower inhibitory activity. The $I C_{50}$ values for $\mathbf{7}$ and $\mathbf{8}$ were not changed in the absence of NO in HUVEC cells. We infer that no competition takes place for the heme binding site of NO. 

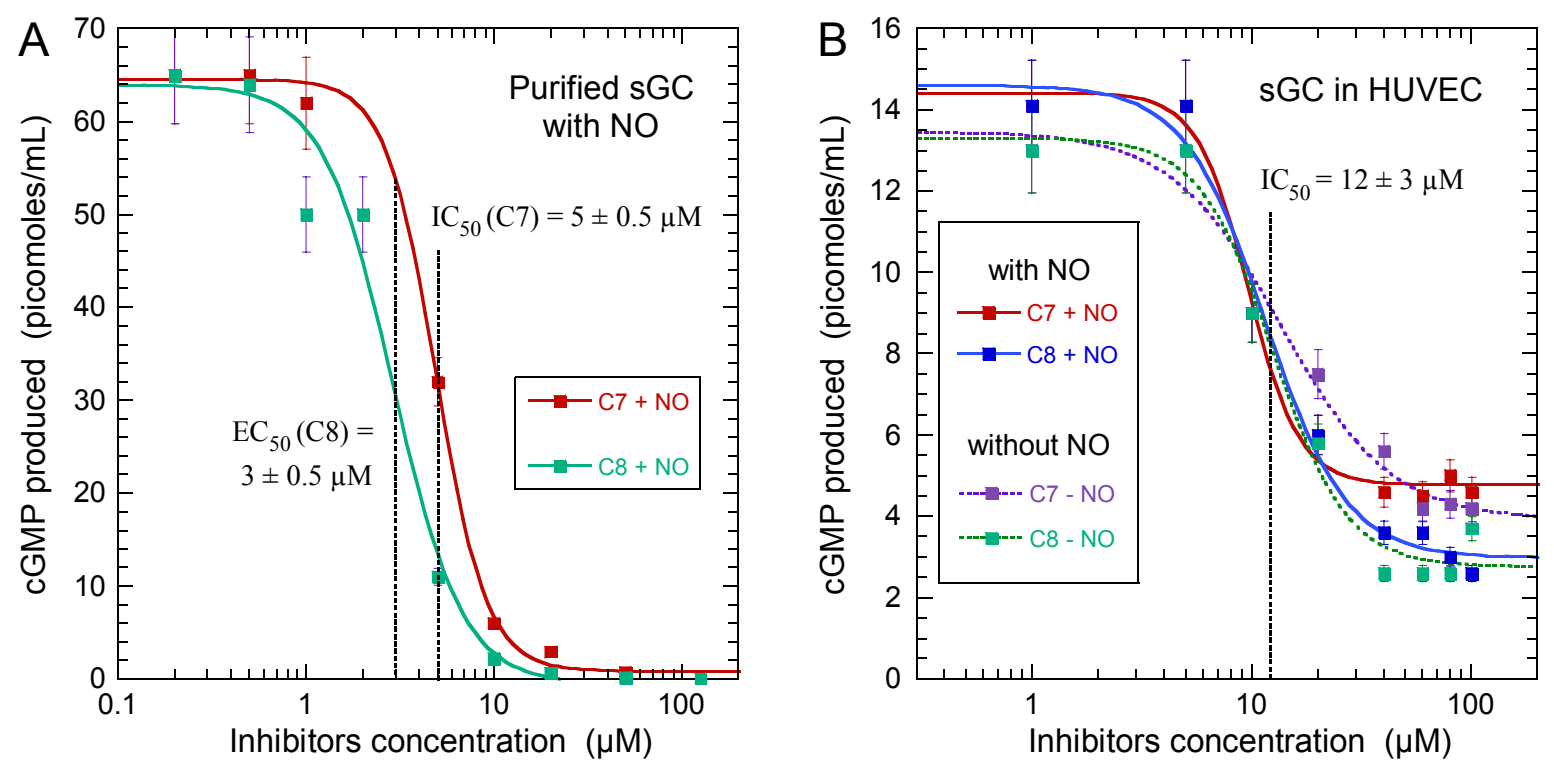

Figure 3. Inhibition of purified sGC activity in vitro (A) and sGC in HUVEC (B) by compounds $\mathbf{7}$ and 8. In HUVEC the activity was measured in the presence and absence of the NO-donor nitroprusside $(300 \mu \mathrm{M})$ during the assay. The density of cells was $4 \times 10^{4}$ cells $/ \mathrm{mL}$. Volume of DMSO added $10 \mu \mathrm{L}$. The respective $I C_{50}$ were calculated from the fit of data to a sigmoid curve. Incubation time of cells with inhibitors 7 and 8 was $48 \mathrm{~h}$. Incubation with HUVEC performed at $37{ }^{\circ} \mathrm{C}$ with $\mathrm{CO}_{2}$ in the dark. The control for all experiment with cells was $1 \%$ DMSO only in the growth medium, which did not inhibit the formation of cGMP. For concentration $\geq 5 \mu \mathrm{M}$ in $\mathrm{A}$ and $\geq 10 \mu \mathrm{M}$ in $\mathrm{B}, p \leq 0.001$.

Cross-Effect of NO with Inhibitors on sGC Activity in HUVEC. We compared the effect of the inhibitors in the presence and absence of NO on sGC activity in cells, verifying whether they are NO-dependent or independent (Figure 3 and 4). We must note that purified SGC cannot be activated in vitro without either NO or an artificial activator (such as BAY412272). Inhibitors 1 and 2 were slightly influenced by NO with a two-fold decrease of $I C_{50}$ to $0.4 \mu \mathrm{M}$ and $0.8 \mu \mathrm{M}$ respectively in the absence of NO (Figure $4 \mathrm{~A}$ ), whereas $\mathbf{3}-\mathbf{5}$ were not influenced by the presence of NO (Figure 4B). For the five compounds, the basal level of cGMP production (in the range $1-5$ picomoles $/ \mathrm{mL}$ ) increased with increasing $I C_{50}$. This level represents cGMP produced during growth of cells, including the period of incubation with inhibitors, but not that produced during the assay which provides external GTP and NO. Inhibitors $\mathbf{1}$ - $\mathbf{5}$ do not compete with NO binding to the heme and do not interfere by attacking NO, a behavior compatible with an allosteric inhibition, locking sGC in the inactivated state. 

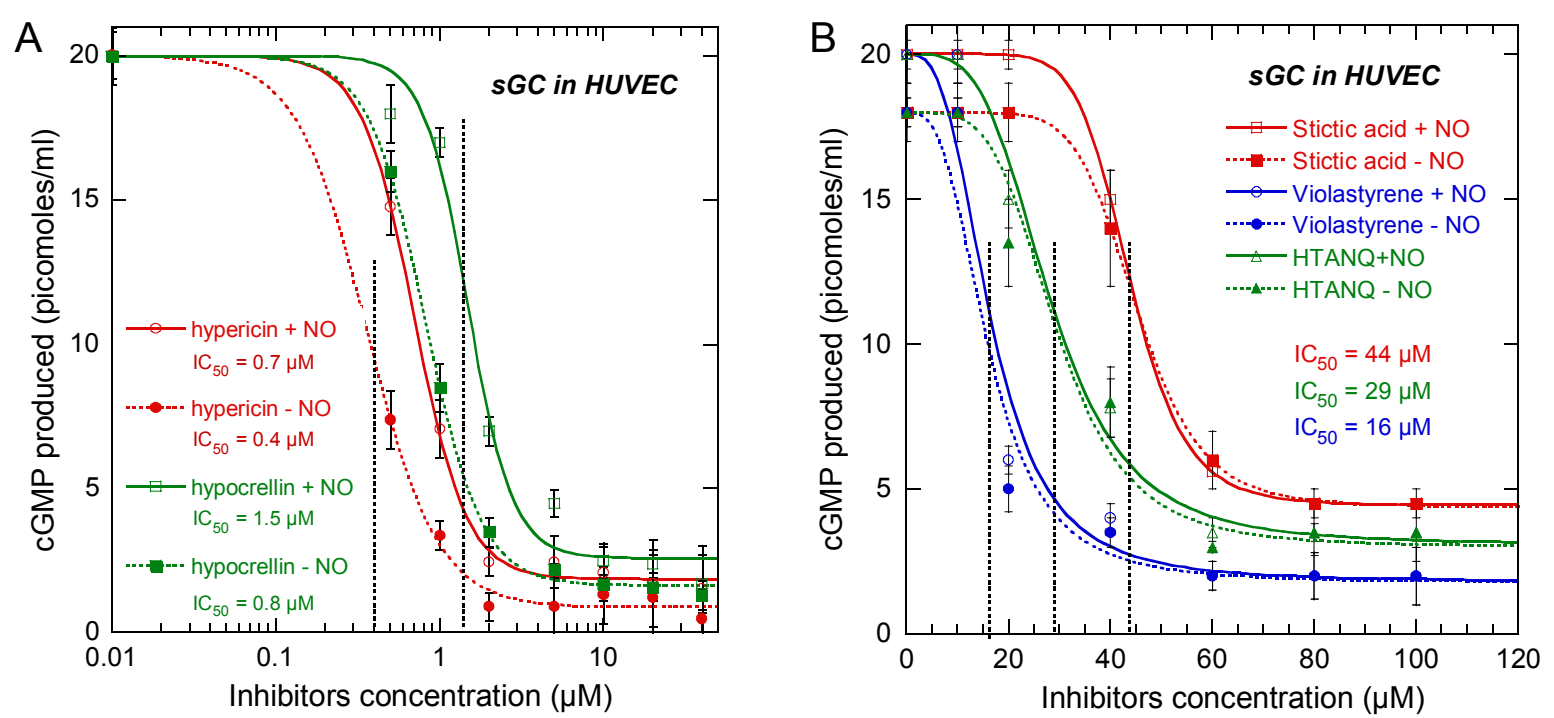

Figure 4. Effect of absence of NO on the inhibition of sGC in HUVEC by compounds $\mathbf{1}-\mathbf{5}$. The NOdonor nitroprusside $(300 \mu \mathrm{M})$ was present or absent in the assay buffer. Density of cells is $5.6 \times 10^{5}$ cells $/ \mathrm{mL}$. The volume of DMSO added is $10 \mu \mathrm{L}$. The $I C_{50}$ were calculated from the fit of data to a sigmoid curve. Incubation time of cells with $\mathbf{1}$ and $\mathbf{2}$ was 2 hours and with $\mathbf{3}-\mathbf{5}$ was 24 h. Incubation performed at $37{ }^{\circ} \mathrm{C}$ with $\mathrm{CO}_{2}$ in the dark. For concentration $\geq 2 \mu \mathrm{M}$ in $\mathrm{A}$ and $\geq 50 \mu \mathrm{M}$ in $\mathrm{B}, p \leq$ 0.001 .

Cross-Effect of Inhibitors and the Activator BAY-412272 on sGC Activity. To identify possible interaction mechanisms, we verified the effect of inhibitors $\mathbf{1}$ and $\mathbf{2}$ in the presence of the activator BAY-412272 that stimulates sGC through a NO-independent regulatory site (not yet identified). Purified sGC and HUVEC were incubated with increasing concentration of 1 or 2 and BAY-412272 $(500 \mu \mathrm{M}$ or $100 \mu \mathrm{M})$ in the presence and absence of NO (Figure 5A). After two hours of incubation with the activator BAY-412272, partial cell death occurred. This observation is reminiscent of the report of cells death induced by $10 \mu \mathrm{M}$ of BAY-412272 in rat pancreatic islets. ${ }^{50}$ We therefore limited to 2 hours the incubation time of HUVEC with the activator at $100 \mu \mathrm{M}$. 

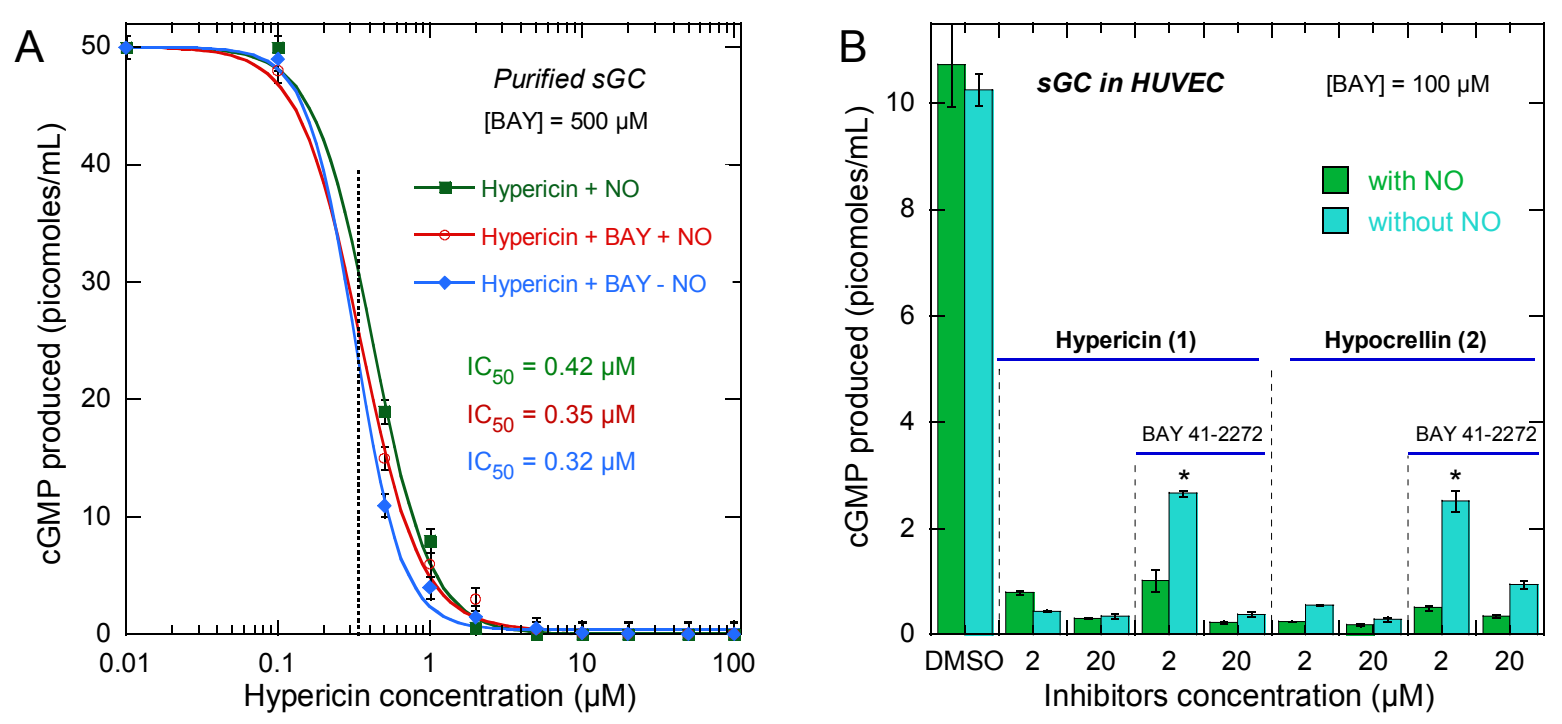

Figure 5. Effect of BAY-412272 on inhibition of sGC activity by $\mathbf{1}$ and $\mathbf{2}$. Assays with purified sGC in vitro (A) and in HUVEC (B). The concentration of BAY-412272 is $500 \mu \mathrm{M}$ for in vitro and $100 \mu \mathrm{M}$ for in vivo experiments. Inhibitors and activator were dissolved in DMSO. Density of cells is $5.6 \times 10^{5}$ cells $/ \mathrm{mL}$. Concentration of nitroprusside is $300 \mu \mathrm{M}$. Standard errors were calculated from triplicate measurements and the $p$-value was calculated with respect to the control incorporating DMSO. $p \leq$ 0.0001 for all measurements except where indicated: ${ }^{*} p \leq 0.001$.

The activator BAY-412272 does not change $I C_{50}$ of $\mathbf{1}$ and $\mathbf{2}$ toward purified sGC in vitro (Figure 5A). This result suggests no competition between the inhibitors and activator. In HUVEC, at $2 \mu \mathrm{M}$ concentration of 1 or 2 , BAY-412272 $(100 \mu \mathrm{M})$ partially restored sGC activity, the formation of cGMP being enhanced $\sim 3-4$ times compared to the absence of activator (Figure 5B), although 1 and 2 at $2 \mu \mathrm{M}$ inhibit sGC in vitro up to $95 \%$. However, the rescue effect of the activator is abolished at $20 \mu \mathrm{M}$ of $\mathbf{1}$ and is decreased 2-fold for 2 . The partial effect of BAY-412272 in HUVEC compared to sGC in vitro is explained by the different ability of inhibitors and activator to pass through the cell membrane. We note that at $2 \mu \mathrm{M}$ of 1 or 2 the simultaneous presence of NO induced a decrease of cGMP, a result that could seem paradoxical, but which is coherent with a possible oxidation of the heme by these inhibitors, like ODQ. ${ }^{51}$ Indeed, $\mathbf{1}$ is involved in the production of reactive oxygen species, even in the absence of light, as used in phototherapy. ${ }^{52}$ The binding of NO to the oxidized heme $\left(\mathrm{Fe}^{3+}\right)$ induces the formation of a desensitized and inactive conformation of sGC. ${ }^{53}$

The activator BAY 41-2272 slightly increased $I C_{50}$ of inhibitors 3 to 6 with purified sGC (Figure 6), with factors ranging from 2 to $\sim 8$ times in the case of $3(0.3$ and $2.5 \mu \mathrm{M}$ in the absence and presence of BAY 41-2272, respectively) and the presence of NO induces an observable effect only in the case of 4 (Table 2). Thus, the activator BAY 41-2272 at $100 \mu \mathrm{M}$ could partially rescue sGC from inhibition. The $K_{\mathrm{D}}$ of BAY 41-2272 changes from $17 \mu \mathrm{M}$ 
when sGC heme is free to $0.08 \mu \mathrm{M}$ when the heme site is occupied by $\mathrm{CO}$ due to allosteric effect. $^{21,54}$ For this reason we discarded the possibility of competitive binding between the inhibitors and BAY 41-2272. Similarly, we did not observe changes of $I C_{50}$ as a function of NO when the activator is present, and thus the binding of inhibitors to the heme (NO binding site) was excluded.

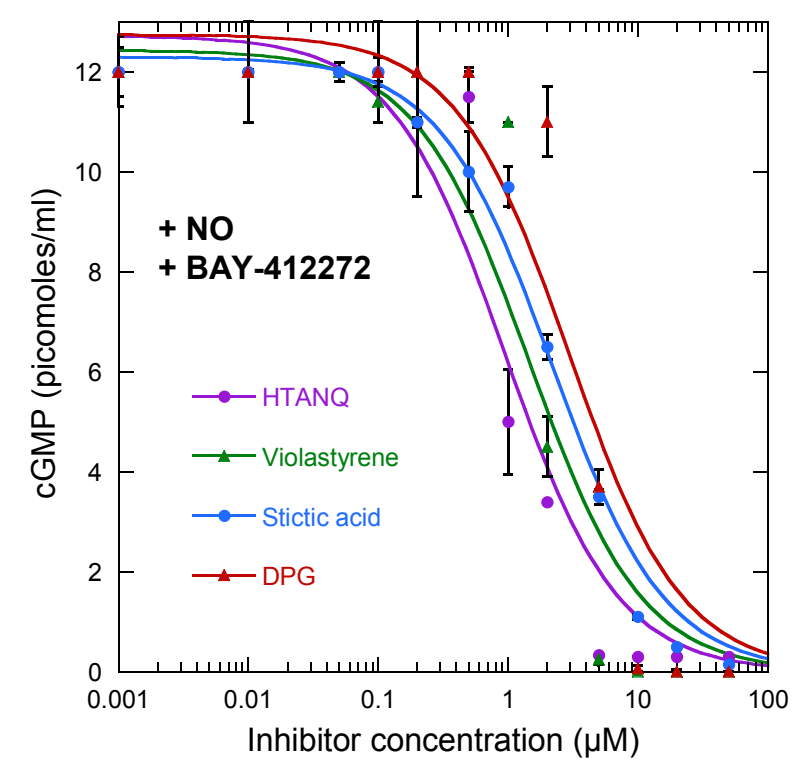

Figure 6. Effect of the sGC activator BAY412272 on the inhibition of purified sGC by 3 $-\mathbf{6}$ in the presence of NO. [BAY-412272] $=$ $100 \mu \mathrm{M}$. For concentration $\geq 2 \mu \mathrm{M}, p \leq 0.001$.

Table 2. Inhibition constants of $\mathbf{1}-\mathbf{6}$ for purified sGC activated by NO and/or BAY-412272.

\begin{tabular}{|c|c|c|c|c|}
\hline \multirow{2}{*}{ Compound } & \multicolumn{3}{|c|}{ IC $_{\mathbf{5 0}}(\boldsymbol{\mu M})$} \\
\cline { 3 - 5 } & + NO & $\begin{array}{c}\text { BAY-412272 } \\
+ \text { NO }\end{array}$ & $\begin{array}{c}\text { BAY-412272 } \\
\text { alone }\end{array}$ \\
\hline $\mathbf{1}$ & Hypericin & $0.4 \pm 0.04$ & $0.35 \pm 0.05$ & $0.32 \pm 0.05$ \\
\hline $\mathbf{2}$ & Hypocrellin A & $1.5 \pm 0.2$ & \multicolumn{2}{c|}{ Not measured } \\
\hline $\mathbf{3}$ & Stictic acid & $0.3 \pm 0.04$ & $2.5 \pm 0.2$ & $2.6 \pm 0.1$ \\
\hline $\mathbf{4}$ & Violastyrene & $0.8 \pm 0.05$ & $1.8 \pm 0.1$ & $4.9 \pm 0.1$ \\
\hline $\mathbf{5}$ & HTANQ & $0.5 \pm 0.07$ & $1 \pm 0.1$ & $1.4 \pm 0.05$ \\
\hline $\mathbf{6}$ & DBPG & $0.7 \pm 0.1$ & $2.9 \pm 0.5$ & - \\
\hline
\end{tabular}

Do the Discovered Inhibitors Oxidize the Heme? All discovered inhibitors possess unsaturated aromatic rings and electronically absorb in the UV-visible range, overlaping the Soret band of the sGC heme to various extents (Figure 7A), the compound 4 having the 
lowest absorption. We verified by absorption spectroscopy the possible heme-oxidizing properties of compounds $\mathbf{3}-\mathbf{8}$. Compounds $\mathbf{1}$ and $\mathbf{2}$ have a too strong overlaping absorption in the entire UV-visible range. The full-length sGC $(2 \mu \mathrm{M})$ was incubated with inhibitors at $20 \mu \mathrm{M}$, well above their $I C_{50}$ (Table 1), for two hours before the measurement of equilibrium spectra. In the absence of inhibitors, the maximum of the Soret absorption band of purified full-length sGC is located at $432 \mathrm{~nm}$ with a broad Q-band centered at $573 \mathrm{~nm}$ in the ferrous heme state $\left(\mathrm{Fe}^{2+}\right)^{54,55}$ whereas a value close to $393 \mathrm{~nm}$ is the signature of the ferric heme state $\left(\mathrm{Fe}^{3+}\right){ }^{56,57}$

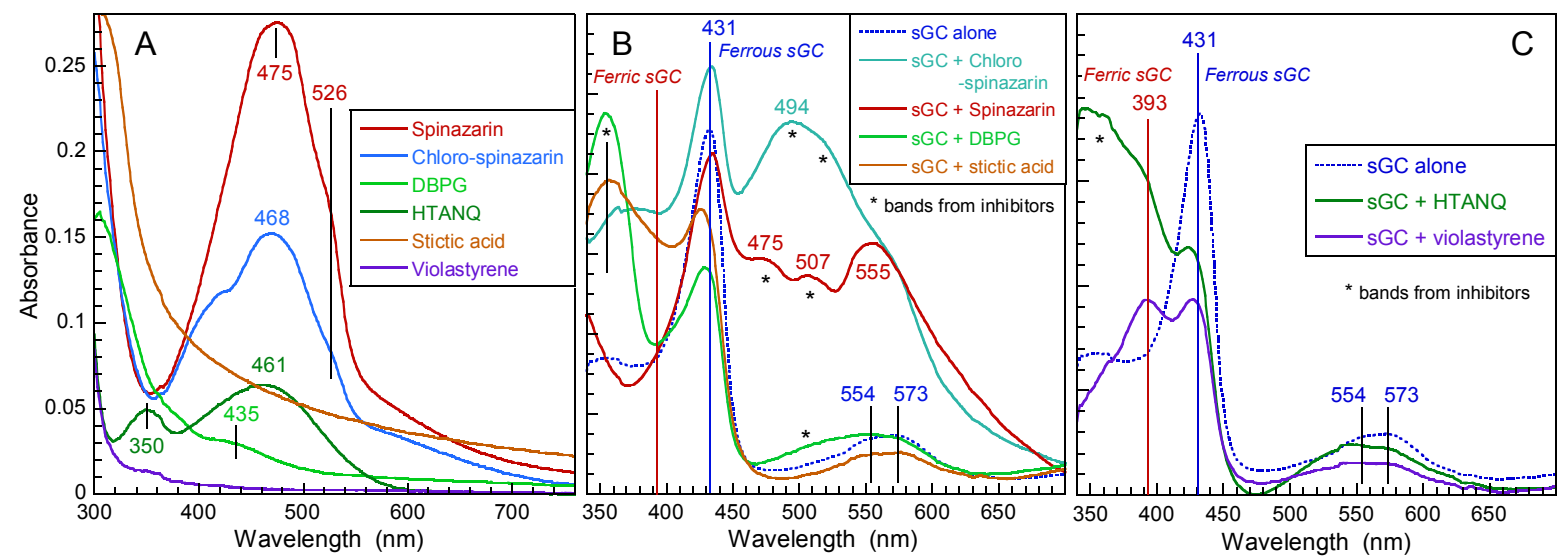

Figure 7. (A) Absorption spectra of pure sGC inhibitors in TEA buffer/DMSO $2.5 \%$. Concentration of all compounds $=20 \mu \mathrm{M}$. Optical path length $=1 \mathrm{~cm}$. (B and $\mathbf{C}$ ) Equilibrium spectra of full-length sGC in the absence and presence of the inhibitors. The band at $393 \mathrm{~nm}$ corresponds to oxidized state $\mathrm{Fe}^{3+}$ of the heme of sGC and band at $432 \mathrm{~nm}$ to $\mathrm{Fe}^{2+}$ heme state of sGC. The symbol * indicates a spectral contribution of the inhibitors without sGC. The four inhibitors $\mathbf{3}, \mathbf{6}, 7$ and $\mathbf{8}$ do not oxidize the heme (B) whereas the two inhibitors 4 and $\mathbf{5}$ oxidize the heme of sGC (C). [sGC] $=2 \mu \mathrm{M}$, [inhibitors] $=20 \mu \mathrm{M}$. Incubation time of inhibitors with sGC before measuring the equilibrium spectra was $2 \mathrm{~h}$. Optical path length $=1 \mathrm{~cm}$.

The presence of $\mathbf{3}$ and $\mathbf{6}$ did not induce a Soret band shift at $393 \mathrm{~nm}$ in sGC spectrum (Figure 7B), indicating that they do not oxidize the heme, as observed in the case of an inhibitor (a fluoro-indolyl-pyrrolidine-dione) bound to the heme enzyme indoleaminedioxygenase. ${ }^{58}$ However the Soret band is slightly shifted to 425 and $428 \mathrm{~nm}$ in the presence of compounds 3 and 6 respectively, suggesting a structural change in the heme vicinity, while keeping the heme redox state. Remarkably, the absorption bands of inhibitors 7 and $\mathbf{8}$ changed upon binding to sGC (Figure 7A and B), which reveals their interaction with the protein. Consequently, it was not possible to subtract their individual spectrum from that of the complex sGC/inhibitor. The sGC spectrum in the presence of compounds $\mathbf{7}$ and $\mathbf{8}$ did not 
either show a shifted Soret band to $393 \mathrm{~nm}$ (Figure 7B) indicating that the sGC heme is not oxidized in their presence. The addition of 4 to sGC led to the appearance of a second Soret peak at $393 \mathrm{~nm}$ and a shift of the Q-bands to $550-571 \mathrm{~nm}$ (Figure 7C), indicating about $50 \%$ of heme in the oxidized state $\left(\mathrm{Fe}^{3+}\right)$. In the presence of sGC, a broad band in near-UV at 350 $\mathrm{nm}$ due to 5 increased, together with the disappearance of the inhibitor band located at $461 \mathrm{~nm}$ when it is alone (Figure 7A). We assigned the shoulder located at $393 \mathrm{~nm}$ (Figure 7C) to the oxidized heme because the amplitude of the Soret band at $431 \mathrm{~nm}$ decreased with respect to sGC alone. The changes induced in the spectrum of $\mathbf{5}$ did not allow to calculate the spectral difference of inhibitor-bound sGC with respect to free sGC. The Q-bands were also shifted from ferrous to ferric heme state in the presence of 5. A well studied sGC inhibitor acting through heme oxidation is $\mathrm{ODQ}^{51,56}$ and a mechanism was proposed to explain its oxidizing action which involves transfer of an electron from heme to ODQ to generate an ODQ radical. ${ }^{56}$ One must note that ODQ also oxidizes hemoglobin. ${ }^{56}$ Structures of ODQ, 4 and $\mathbf{5}$ are quite different (Supporting Figure S4) although ODQ and 5 share a ketone group coupled to a ring, whereas $\mathbf{5}$ possesses ester and $\mathbf{4}$ only two methoxy groups. It is not possible to infer the exact electron transfer mechanism involving the inhibitors $\mathbf{4}$ and $\mathbf{5}$ from their spectra, a question beyond the scope of the present study.

Thus compounds $\mathbf{4}$ and $\mathbf{5}$ oxidize the heme of sGC which cannot be activated by diatomic ligands in the ferric state ${ }^{59}$ and may be subject to heme loss, ${ }^{60}$ whereas the inhibition mechanism of other compounds which do not oxidize the heme $(\mathbf{1}-\mathbf{3}, \mathbf{6}-\mathbf{8})$ is still unknown but is inferred to be allosteric.

Anti-angiogenic Activity of sGC Inhibitors. We then evaluated the ability of five selected inhibitors to slow down or to stop angiogenesis in cultured human endothelial progenitor cells (HEPC-CB1). ${ }^{91}$ In these model cells the evolution of pseudo-vessels were followed over 22 hours in the presence or the absence of the sGC inhibitors. After 13 hours of cell growth the formation of pseudo-vessels was indeed slowed down and their geometry modified with respect to the cells in absence of compounds (Figure 8). The total length of pseudo-vessels, the number of closed structures and of pseudo-vessels were quantified (Supporting Figure S5), indicating that compounds 1 and 2 at $10 \mu \mathrm{M}$ induced a drastic decrease of the three parameters, in agreement with their $I C_{50}$ in vitro. Compounds 3 and $\mathbf{6}$ also induced their decrease at $30 \mu \mathrm{M}$, with an $I C_{50}$ apparently lower than in HUVEC (Table 1) whereas compound 7 decreased 2-fold the three parameters both at 10 and $30 \mu \mathrm{M}$, in line with the partial inhibition observed in HUVEC (Figure 3A). The effect of sGC inhibition on angiogenesis demonstrated here agrees with similar effects obtained in another endothelial 
cell model by the inhibition of endothelial NO-synthase, ${ }^{34}$ the immediate upstream partner of sGC in the NO/cGMP pathway.

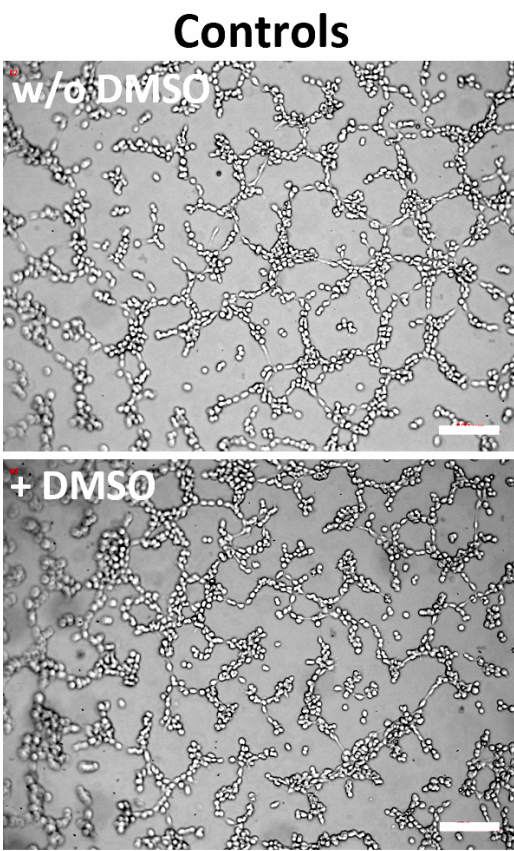

stictic acid (3)
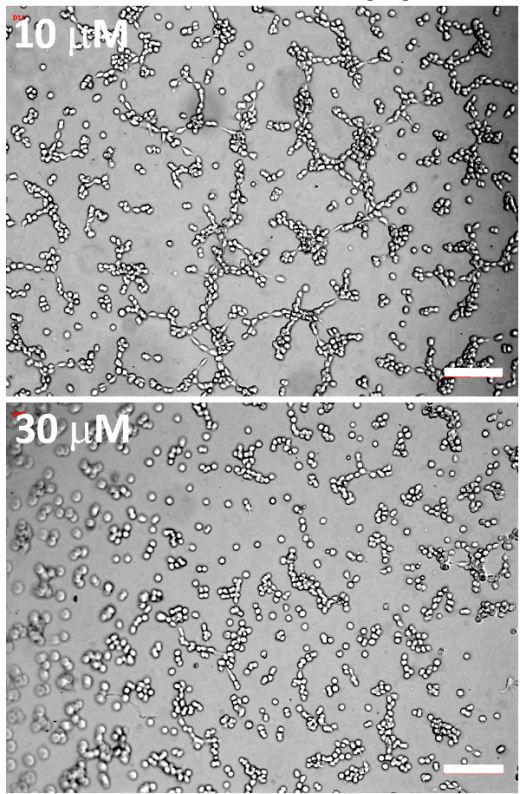

hypericin (1)
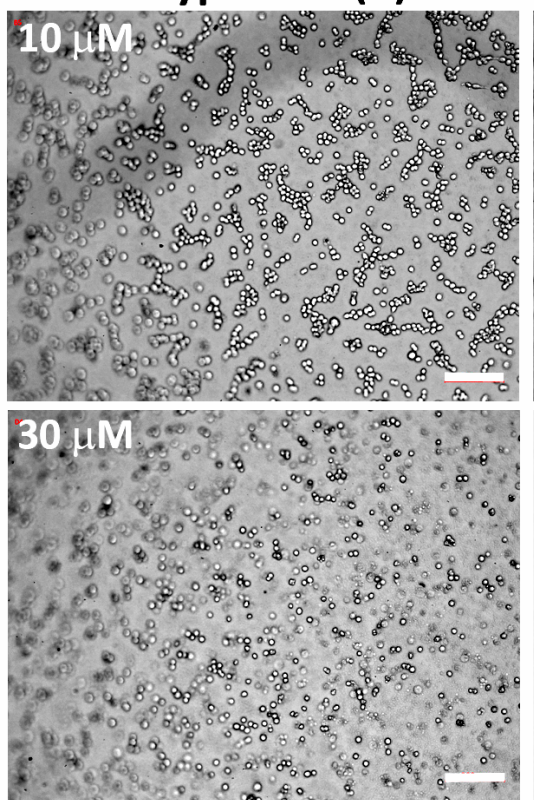

DBPG (6)
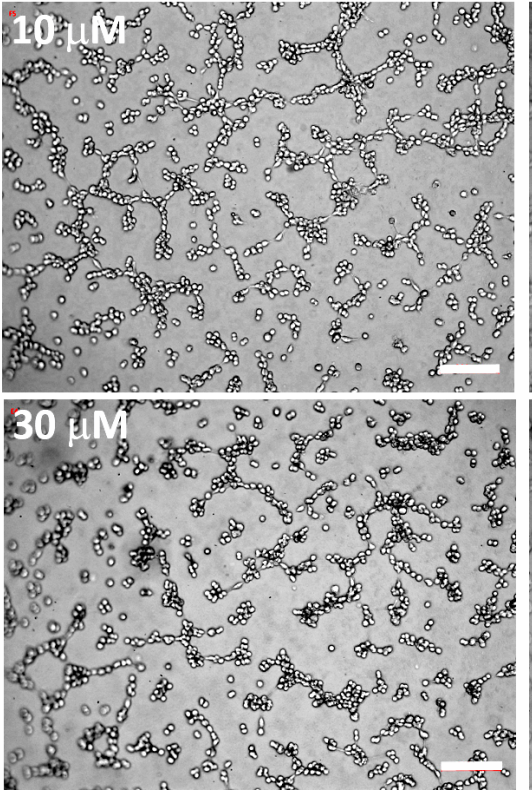

hypocrellin (2)
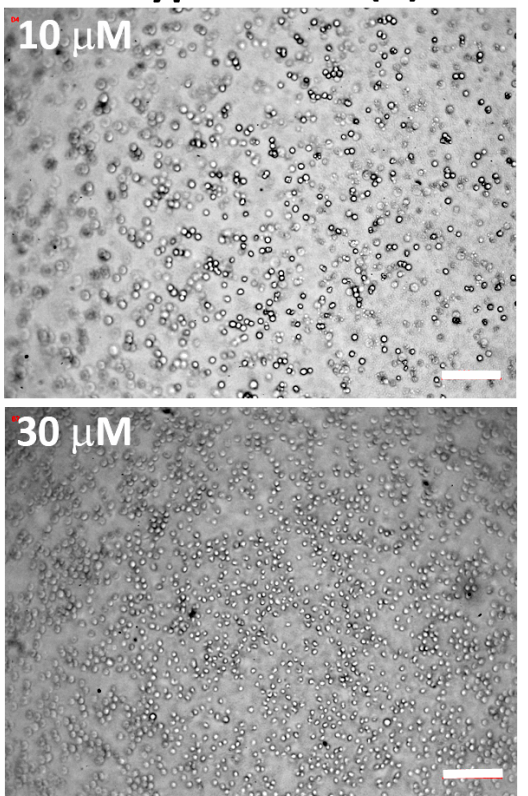

spinazarin (7)

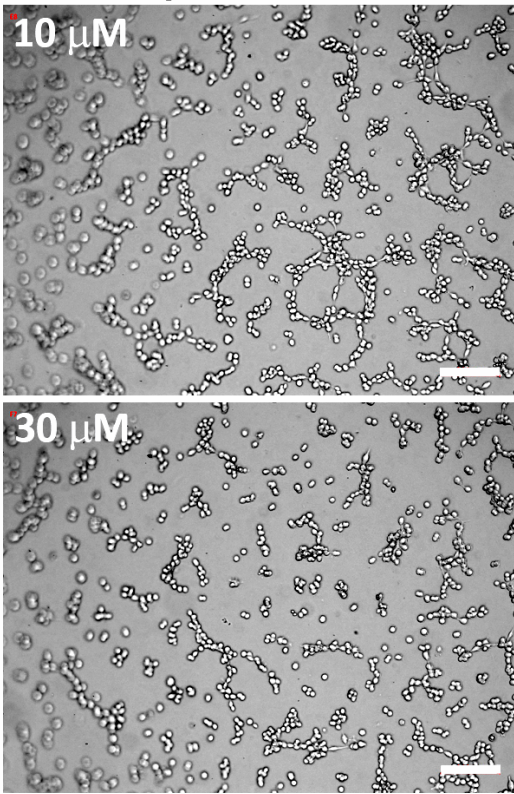

Figure 8. Inhibition of endothelial cell angiogenesis by sGC inhibitors. The angiogenesis of HEPC.CB1 on Matrigel ${ }^{\mathrm{TM}}$, in the presence of 10 and $30 \mu \mathrm{M}$ of hypericin (1), hypocrellin (2), stictic acid (3), DBPG (6) or spinazarin (7) was monitored under a videomicroscope. Photos are presented after $13 \mathrm{~h}$ of culture on Matrigel ${ }^{\mathrm{TM}}$. In all images the scale bar represents $200 \mu \mathrm{m}$. Controls have been performed without and with DMSO at same final concentration $(0.5 \%)$ used after introducing the inhibitors. 


\section{DISCUSSION}

Activities of the Discovered sGC Inhibitors Toward Other Enzymes. We have previously measured a decreased cellular cGMP level in the presence of 1 (at $4 \mu \mathrm{M}$ ) in cardiomyocytes, ${ }^{45}$ together with an increased conductance of L-type $\mathrm{Ca}^{2+}$ channels, that was assigned to sGC inhibition, a hypothesis fully confirmed by the present results. Beyond its study for photodynamic therapy, ${ }^{61} \mathbf{1}$ was shown to have effects on various cell signaling pathways. ${ }^{52}$ Numerous studies focussed on Hypericum perforatum extract (i.e. not purified compounds), but some target proteins were identified for $\mathbf{1}$, including c-type kinases, ${ }^{62}$ proteins involved in breast cancer resistance, ${ }^{63}$ glutathione-S-transferases (with $\mathrm{Ki}$ in the range $0.2-2.5 \mu \mathrm{M})^{64}$ and dopamine- $\beta$-hydroxylase with an $I C_{50}$ of $21 \mu \mathrm{M} .^{65}$ Importantly, $\mathbf{1}$ was shown to reduce angiogenesis in several ocular models ${ }^{66,67}$ by inhibiting phosphorylation of MAP kinases. ${ }^{68}$ Both 1 and $\mathbf{2}$ can also bind to human serum albumin. ${ }^{68}$ Although its physiological effects were much less investigated than $\mathbf{1}$, compound $\mathbf{2}$ was also tested for photodynamic therapy and induces the decrease of endothelin-1 and VEGF in HUVEC, probably through inhibition of PKC. ${ }^{69}$

Albeit few studies reported pharmacological activity of $\mathbf{3}$, it induces intracellular lactate dehydrogenase release, linked to apoptosis of hepatocytes $\left(13 \mu \mathrm{M}<I C_{50}<230 \mu \mathrm{M}\right) .^{70}$ Importantly, stictic acid has tumor-suppressing effects via reactivation of p53 protein mutants in cancer cells. ${ }^{71}$ It was also shown to inhibit competitively two bacterial $\beta$-hydroxyacyl-acyl carrier protein dehydratases $\left(I C_{50}=13-28 \mu \mathrm{M}\right) .^{72}$ No physiological action is known for compounds 4, 5 and $\mathbf{6}$, whereas the only effect reported for $\mathbf{7}$ and its derivative $\mathbf{8}$ is the scavenging of free radicals. ${ }^{73}$

Therapeutic Uses of the Discovered sGC Natural Inhibitors. As described in Introduction, sGC is involved particularly in cancer, apoptosis and angiogenesis. It has also a central role in vasoplegia (also called vasodilatory shock) whose causes can be multiple ${ }^{37,74}$ and is characterized by a drop of blood pressure, the treatment of which appears critical. ${ }^{37}$ Proposed vasoplegia treatments include the use of adrenergic vasopressors to restore blood pressure, but blood vessels may not respond to vasopressors even at high concentration. A more efficient treatment has been proposed by inhibiting directly $\mathrm{sGC}^{75,76}$ essentially by means of methylene blue ${ }^{76-78}$ whose action on coronary arteries has been recognized ${ }^{79}$ soon after the discovery of the role of NO as a messenger. However, methylene blue is not specific, 
since it inhibits constitutive NO-synthase ${ }^{80}$ and other enzymes, ${ }^{81}$ similarly with $\mathrm{ODQ}^{82}$ and can hardly be used as a therapeuthic agent. More specific sGC inhibitors are needed here.

The NO/cGMP cell signaling has been recognized to be involved in regulating the interactions between dopamine and glutamate neurotransmission in striatum. ${ }^{83}$ The administration of the sGC inhibitor ODQ could reverse markers of ganglia dysfunction in a rat model, ${ }^{38}$ so that sGC inhibition has been proposed as a treatment of parkinsonian symptoms. ${ }^{38}$ The oxidant sGC inhibitors ODQ and methylene blue could reduce dyskinesia induced by L-dihydroxyphenylalanine in rats. ${ }^{84}$ Related to this issue, the role of sGC has also been shown in the neurodegeneration in Drosophila ${ }^{85}$ which was improved by treatment with the NOS inhibitor L-NAME (nitro-L-arginine-methyl-ester), inhibiting the NO/sGC pathway.

sGC is involved in many cell signaling pathways which may have the ability of counteracting each other in therapeutic action (e. g. apoptosis versus tumoral angiogensis). It is obvious that, like most of drugs, the use of sGC activators or inhibitors may have sideeffects, yet, strong benefits from their use are expected. A promissing method of removing (or at least attenuating) side-effects would be to associate inhibitors with a strategy to target organs for drug delivery. In this view, the use of sGC inhibitors as drugs for angiogenesis will benefit from advances of nanoparticles (especially bionanoparticles) for targeted drug delivery, ${ }^{86,87}$ which is a very active field in chemical biology. Promising systems consist of cell membrane-based drug carriers. ${ }^{88,89}$ Both fields of research must progress in parallel.

\section{CONCLUSIONS}

The natural compounds from plants and fungi described here are the first molecules reported so far to inhibit sGC in vitro with $I C_{50}$ in the range $0.2 \mu \mathrm{M}-1.5 \mu \mathrm{M}$, although some of their properties remain to be evaluated. Further advances require to know the architecture of the inhibitors binding site(s) and to co-crystallize the full-length sGC with the compounds described here, but it appeared impossible to obtain crystals of sGC, certainly because of its flexibility. ${ }^{19}$ However, a full three-dimensional structure model ${ }^{90}$ from a cryoelectromicroscopy template ${ }^{19}$ and from X-ray crystallographic models of the different domains (H-NOX, PAS and catalytic domains) can be used for calculations. The crossreactivity of compounds with NO and the sGC activator BAY 41-2272 suggests an allostric mechanism. These discovered inhibitors can be used directly as tools for investigating the role of sGC in signaling pathways. Importantly, they provide templates amenable to improvement for drug design to target tumoral angiogenesis or vasoplegia, both involving sGC. 


\section{EXPERIMENTAL SECTION}

Enzymes, Cells and Natural Compounds. We used either sGC from bovine lung purified as previously described ${ }^{55}$ or full-length recombinant human sGC purchased from Alexis (ALX-201-177). Human umbilical vein endothelial cells (HUVEC) isolated from normal vein were purchased from Gibco. Purified hypericin and hypocrellin (98\% purity) were purchased from Invitrogen and the activator BAY-412272 (98 \% purity) from Enzo. The chemical library containing 320 natural compounds (GPNCL, Greenpharma) and some isolated compounds from Ambinter (naphtoquinone derivatives Amb537501 and Amb537686 and violastyrene derivatives, $98 \%$ purity). These compounds comprises mostly alkaloids, phenol derivatives and terpenoids from plants and fungi. Each compounds from the library was first tested at a concentration of $20 \mu \mathrm{M}$ for its effect on catalytic activity of the purified sGC (inhibition or activation). Then the effects of the more active compounds at $20 \mu \mathrm{M}$ were tested as a function of increasing concentration on both purified sGC and HUVEC.

Catalytic Activity of Purified sGC. Activity measurements were carried out on purified sGC as previously described ${ }^{45}$ with minor modifications. All compounds from Greenpharma library, hypericin, hypocrellin and the activator BAY-412272 were first diluted in pure DMSO to get a stock solution, then in $\mathrm{H}_{2} \mathrm{O}$ at the desired working concentration. Purified sGC was resuspended in TEA buffer: triethanolamine $25 \mathrm{mM}, \mathrm{NaCl} 10 \mathrm{mM}$, dithiothreitol (DTT) 1 $\mathrm{mM}, \mathrm{pH}$ 7.4. Selected inhibitors at increasing concentration were mixed with sGC at $100 \mathrm{nM}$ and incubated in the dark, either 2 hours at $20{ }^{\circ} \mathrm{C}$ or overnight at $4{ }^{\circ} \mathrm{C}$. When investigating the cross-effect of BAY-412272, this activator was mixed together with inhibitors. The final concentration of DMSO is $2.5 \%$. Then sGC ( $25 \mathrm{nM}$ final concentration) was incubated in assay buffer (100 $\mu \mathrm{L}$ final volume) for 10 minutes at $37{ }^{\circ} \mathrm{C}$. The assay buffer composition was: TEA $100 \mathrm{mM}$, pH 7.4, DTT $1 \mathrm{mM}, \mathrm{MnCl}_{2} 3 \mathrm{mM}$, GTP $0.6 \mathrm{mM}$, creatine phosphate 5 $\mathrm{mM}$, creatine phosphokinase $150 \mathrm{U} / \mathrm{L}$, nitroprusside (NPS) $0.3 \mathrm{mM}$. The NO-donor NPS was omitted for assays in absence of NO. The reaction was stopped by precipitation with $\mathrm{Zn}$ acetate and $\mathrm{Na}_{2} \mathrm{CO}_{3}$ and $40 \mu \mathrm{L}$ of supernatant are used for assaying the synthetized cGMP. After this step, the immunoenzymatic assay was performed using commercial ELISA kits, either from Enzo (ADI-901-013) or from GE-Healthcare (RPN 226), according to manufacturer's instructions, with the acetylation protocole. A standard curve of known cGMP concentrations was measured together each experiment allowing to calculate produced cGMP from the absorbance. 
Catalytic Activity of sGC in HUVEC. The multiplication of HUVEC cells was realized with complete medium (Medium 200 or 200PRF), low serum growth supplement (LSGS) X50 factor, antibiotic X100 factor, serum bovine albumin (10\% from all of volume). HUVEC were grown in 12-well plates (individual surface $3.8 \mathrm{~cm}^{2}$ ). When the cells were at $\sim 90 \%$ confluence, the medium was replaced (500 $\mu \mathrm{L}$ final volume) and inhibitors at varying concentrations (10 $\mu \mathrm{L} ; 2 \%$ DMSO final concentration) were added in the wells, (or only DMSO for control) then incubated for 24 hours in a $\mathrm{CO}_{2}$ incubator at $36{ }^{\circ} \mathrm{C}$ in the dark. Some compounds necessitated up to $24 \mathrm{~h}$ incubation with HUVEC due to their low hydrophobicity and ability to pass through cell membrane. The cells incubated with compounds were then lyzed for 20 minutes with $50 \mu \mathrm{L}$ of the following lysis buffer: TEA $500 \mathrm{mM}$, isobutylmethylxanthine (IBMX) $10 \mathrm{mM}$, Triton X100 $10 \%, \mathrm{pH}=7.4$. The lyzed cell suspension was incubated directly in the wells of the culture plate with same assay buffer ( 50 $\mu \mathrm{L} ; 10 \mathrm{X}$ ) as used for purified sGC (in the presence or absence of NPS) for 20 minutes with mild shaking at room temperature. Then, $500 \mu \mathrm{L}$ of solution from each well were transfered into polypropylene tubes for acetylation of the synthesized cGMP. After this step, immunoenzymatic assay of cGMP was performed with the ELISA kit as performed for the purified protein. Where applicable, statistic evaluation of the data was perform by calculating the $p$-value with Anova test implemented in Kaleidagraph V3.6 (Synergy Software).

Assay of the Anti-angiogenic Activity of Natural Compounds. The human endothelial progenitor cell line HEPC-CB1, which was established and characterized in our laboratory, ${ }^{91}$ was used to assess the anti-angiogenic properties of five compounds. Cells were briefly treated with trypsin (Invitrogen), washed and were seeded at $1.5 \times 10^{4}$ cells/well in serum-free Opti-MEM medium, in the presence of two different concentrations of compounds on 96-well plates coated with Matrigel ${ }^{\mathrm{TM}}$ (BD Biosciences, San José, CA). The final concentration of DMSO was kept at $0.5 \%$. Cultures were performed at $37{ }^{\circ} \mathrm{C}$ with $5 \% \mathrm{CO}_{2}$ in the videomicroscope incubation chamber. Cell rearrangement and pseudo-vessels formation were visualized using an AXIO OBSERVER Z1 fluorescence inverted microscope (Zeiss, Le Pecq, France) equipped with a high-resolution numeric camera linked to a computer driving the acquisition software Zen (Zeiss). The direct real-time visualization of the formation of pseudo-vessels was monitored during $22 \mathrm{~h}$. Angiogenesis was quantified by the determination of pseudo-vessel number, closed structures (meshes) number and by the measurement of pseudo-vessel total length using Image J software with the Angiogenesis analyzer add-on.

Spectroscopy. The absorption spectra of sGC and inhibitors were measured with a UV-1700 Shimadzu spectrophotometer in a $1 \times 1 \mathrm{~cm}$ QX-quartz cell (Hellma) at $20{ }^{\circ} \mathrm{C}$. The 
concentrations used were $[\mathrm{sGC}]=2 \mu \mathrm{M}$ and [inhibitors $]=20 \mu \mathrm{M}$. The inhibitors were incubated with sGC during $2 \mathrm{~h}$ before measuring the spectra at equilibrium.

\section{ASSOCIATED CONTENT}

Supporting Information is available.

\section{AUTHOR INFORMATION}

\section{Corresponding Author}

Michel Negrerie - Laboratoire d'Optique et Biosciences, INSERM U1182, Ecole Polytechnique, Palaiseau,France. Email: michel.negrerie@polytechnique.edu Phone: 13369335052.

ORCID: 0000-0001-9918-031X

\section{Authors}

Olga N. Petrova - Laboratoire d'Optique et Biosciences, INSERM U1182, Ecole Polytechnique, Palaiseau, France. Present address : Handicap Neuromusculaire: Physiologie, Biothérapie et Pharmacologie Appliquées, Inserm U1179, Université de Versailles Saint-Quentin-en-Yvelines, Montigny-le-Bretonneux, France.

Isabelle Lamarre - Laboratoire d'Optique et Biosciences, INSERM U1182, Ecole Polytechnique, Palaiseau, France.

Fabienne Fasani - Centre de Biophysique Moléculaire, UPR4301 CNRS, Orléans, France.

Catherine Grillon - Centre de Biophysique Moléculaire, UPR4301 CNRS, Orléans, France.

\section{Notes}

The authors declare no competing financial interest.

\section{AKNOWLEDGMENTS}

O. N. P. acknowledges an "Initiative Doctorale Interdisciplinaire" fellowship from Université Paris-Saclay. The authors thank David Gosset for his assistance in imaging angiogenesis on the P@CYFIC platform facility at the Center for Molecular Biophysics (Orléans, France).

\section{ABBREVATIONS}

sGC, soluble guanylate cyclase; eNOS, endothelial NO-synthase; cGMP, 3',5'-cyclic guanosine monophosphate; GTP, guanosine 5'-triphosphate; PKG, cGMP-activated protein 
kinase; IP3, inositol triphosphate; HTANQ, 2-hydroxy-3,5,8-triaceto-1,4-naphthoquinone; DMSO, dimethylsulfoxide; DPG, 3,6-dibromo-purpurogallin. ODQ, $\quad 1 \mathrm{H}-[1,2,4]-$ oxadiazolo[4,3-a]quinoxalin-1-one; HUVEC, human umbilical vein endothelial cells. VEGF, vascular endothelial growth factor; IBMX, isobutylmethylxanthin; NPS, sodium nitroprusside. HEPC, human endothelial progenitor cell line.

\section{REFERENCES}

(1) Murad, F. Angew. Chem. Int. Ed. 1999, 38, 1857-1868.

(2) Furchgott, R. F. Angew. Chem. Int. Ed. 1999, 38, 1870-1880.

(3) Ignarro, L. J. Angew. Chem. Int. Ed. 1999, 38, 1882-1892.

(4) Ignarro, L. J.; Cirino, G.; Casini, A.; Napoli, C. J. Cardiovasc. Pharmacol. 1999, 34, 879-886.

(5) Buys, E.; Sips, P. Curr. Opin. Nephrol. Hyp. 2014, 23, 135-142.

(6) Nagy, G.; Clark, J. M.; Buzás, E. I.; Gorman, C. L.; Cope, A. P. Immunol. Lett. 2007, 111, $1-5$.

(7) Zhang, G.; Xiang, B.; Dong, A.; Skoda, R. C.; Daugherty, A.; Smyth, S. S.; Du, X.; Li, Z. Blood 2011, 118, 3670-3679.

(8) Garthwaite, J. Br. J. Pharmacol. 2019, 176, 197-211.

(9) Chin, C.-H.; Tsai, F.-C.; Chen, S.-P.; Wang, K.-C.; Chang, C.-C.; Pai, M.-H.; Fong, T.-H. Eur. J. Pharmacol. 2012, 689, 1-7.

(10) Bian, K.; Murad, F. Nitric Oxide 2014, 43, 3-7.

(11) Fraser, M.; Chan, S. L.; Chan, S. S. L.; Fiscus, R. R.; Tsang, B. K. Oncogene 2006, 25, 22032212.

(12) Blaise, G. A.; Gauvin, D.; Gangal, M.; Authier, S. Toxicology 2005, 208, 177-192.

(13) Bian, K.; Doursout, M.; Murad, F. J. Clin. Hypertens. 2008 10, 304-310.

(14) Evgenov, O. V.; Pacher, P.; Schmidt, P. M.; Haskó, G.; Schmidt, H. H. H. W.; Stasch, J.-P. Nat. Rev. Drug Disc. 2006, 5, 755-768.

(15) Lundberg, J. O.; Gladwin, M. T.; Weitzberg, E. Nat. Rev. Drug. Discov. 2015, 14, 623-641.

(16) Stasch, J. P.; Pacher, P.; Evgenov, O. V. Circulation 2011, 123, 2263-2273.

(17) Ko, F.-N.; Wu, C.-C.; Kuo, S.-C.; Lee, F.-Y.; Teng, C.-M. Blood 1994, 84, 4226-4233.

(18) Yoo, B. K.; Lamarre, I.; Martin, J. L.; Rappaport, F.; Negrerie, M. Proc. Natl. Acad. Sci. U. S. A. 2015, 112, E1697-E1704.

(19) Campbell, M. G.; Underbakke, E. S.; Potter, C. S.; Carragher, B.; Marletta, M. A. Proc. Natl. Acad. Sci. U. S. A. 2014, 111, 2960-2965.

(20) Yoo, B.-K.; Lamarre, I.; Rappaport, F.; Nioche, P.; Raman, C. S.; Martin, J. L.; Negrerie, M. ACS Chem. Biol. 2012, 7, 2046-2054.

(21) Purohit, R.; Fritz, B. G.; The, J.; Issaian, A.; Weichsel, A.; David, C. L.; Campbell, E.; Hausrath, A. C.; Rassouli-Taylor, L.; Garcin, E. D.; Gage, M. J.; Montfort, W. R. Biochemistry 2013, $53,101-114$.

(22) Bian, K.; Sotolongo, A.; Lam, H.; Xiao, H.; Zhang, D.; Liu, J.; Murad, F. BMC Pharmacol. Toxicol. 2013, 14, P9.

(23) Mujoo, K.; Sharin, V. G.; Martin, E.; Choi, B.-K.; Sloan, C.; Nikonoff, L. E.; Kots, A. Y.; Murad, F. Nitric Oxide 2010, 22, 43-50.

(24) Zhu, H.; Li, J. T.; Zheng, F.; Martin, E.; Kots, A. Y.; Krumenacker, J. S.; Choi, B.-K.; McCutcheon, I. E.; Weisbrodt, N.; Bögler, O.; Murad, F.; Bian, K. Mol. Pharmacol. 2011, 80, 1076-1084. 
(25) Wen, H.-C.; Chuu, C.-P.; Chen, C.-Y.; Shiah, S.-G.; Kung, H.-J.; King, K.-L.; Su, L.-C.; Chang, S.-C.; Chang, C.-H. PloS One 2015, 10, e0125518-e0125518.

(26) Grimm, E. A.; Ellerhorst, J.; Tang, C.-H.; Ekmekcioglu, S. Nitric Oxide 2008, 19, 133-137.

(27) Leung, E. L.; Wong, J. C.; Johlfs, M. G.; Tsang, B. K.; Fiscus, R. R. Mol. Cancer Res. 2010, $8,578-591$.

(28) Cai, C.; Chen, S. Y.; Zheng, Z.; Omwancha, J.; Lin, M. F.; Balk, S. P.; Shemshedini, L. Oncogene 2006, 26, 1606-1615.

(29) Menéndez, L.; Juárez, L.; García, V.; Hidalgo, A.; Baamonde, A. Neuropharmacology 2007, $53,71-80$.

(30) Park, S.-W.; Lee, S.-G.; Song, S.-H.; Heo, D.-S.; Park, B.-J.; Lee, D.-W.; Kim, K.-H.; Sung, M.-W. Int. J. Cancer 2003, 107, 729-738.

(31) Isenberg, J. S.; Martin-Manso, G.; Maxhimer, J. B.; Robert, D. D. Nat. Rev. Cancer 2009, 9, 182-194.

(32) Pyriochou, A.; Beis, D.; Koika, V.; Potytarchou, C.; Papadimitriou, E.; Zhou, Z.; Papapetropoulos, A. J. Pharmacol. Exp. Ther. 2006, 319, 663-671.

(33) Morbidelli, L.; Pyriochou, A.; Filippi, S.; Vasileiadis, I.; Roussos, C.; Zhou, Z.; Loutrari, H.; Waltenberger, J.; Stoessel, A.; Giannis, A.; Ziche, M.; Papapetropoulos, A. Am. J. Physiol.-Regul. Integr. Comp. Physiol. 2010, 298, R824-R832.

(34) Carreau, A.; Kieda, C.; Grillon, C. Exp. Cell Res. 2011, 317, 29-41.

(35) Collet, G.; Szade, K.; Nowak, W.; Klimkiewicz, K.; El Hafny-Rahbi, B.; Szczepanek, K.; Sugiyama, D.; Weglarczyk, K.; Foucault-Collet, A.; Guichard, A.; Mazan, A.; Nadim, M.; Fasani, F.; Lamerant-Fayel, N.; Grillon, C.; Petoud, S.; Beloeil, J.-C.; Jozkowicz, A.; Dulak, J.; Kieda, C. Cancer Letters 2016, 370, 345-357.

(36) Wong, J. C.; Fiscus, R. R. Cardiovasc. Pathol. 2010, 19, e221-e231.

(37) Kimmoun, A.; Ducrocq, N.; Levy, B. Curr. Vasc. Pharmacol. 2013, 11, 139-149.

(38) Tseng, K. Y.; Caballero, A.; Dec, A.; Cass, D. K.; Simak, N.; Sunu, E.; Park, M. J.; Blume, S. R.; Sammut, S.; Park, D. J.; West, A. R. PloS One 2011, 6, e27187.

(39) Sousa, E. H. S.; de Franca Lopes, L. G.; Gonzalez, G.; Gilles-Gonzalez, M.-A. J. Inorg. Biochem. 2017, 167, 12-20.

(40) Haramis, G.; Zhou, Z.; Pyriochou, A.; Koutsilieris, M.; Roussos, C.; Papapetropoulos, A. Br. J. Pharmacol. 2008, 6, 804-813.

(41) Olesen, S.-P.; Drejer, J.; Axelsson, O.; Moldt, P.; Bang, L.; Nielsen-Kudsk, J. E.; Busse, R.; Mülsch, A. Br. J. Pharmacol. 1998, 123, 299-309.

(42) Luo, D.; Das, S.; Vincent, S. R. Eur. J. Pharmacol. 1995, 290, 247-251.

(43) James, L. R.; Griffiths, C. H.; Garthwaite, J.; Bellamy, T. C. Br. J. Pharmacol. 2009, 158, $1454-1464$.

(44) Mota, F.; Gane, P.; Hampden-Smith, K.; Allerston, C. K.; Garthwaite, J.; Selwood, D. L. Bioinorg. Med. Chem. 2015, 23, 5303-5310.

(45) Sauviat, M.-P.; Colas, A.; Chauveau, M.-J.; Drapier, J.-C.; Negrerie, M. J. Nat. Prod. 2007, $70,510-514$.

(46) Lohézic-Le Dévéhat, F.; Tomasi, S.; Elix, J. A.; Bernard, A.; Rouaud, I.; Uriac, P.; Boustie, J. J. Nat. Prod. 2007, 70, 1218-1220.

(47) Yakubovskaya, A. Y.; Pokhilo, N. D.; Mishchenko, N. P.; Anufriev, V. F. Russian Chem. Bull. 2007, 56, 819-822.

(48) Delaey, E. M.; Obermuëller, R.; Zupko, I.; De Vos, D.; Falk, H.; de Witte, P. A. M. Photochem. Photobiol. 2001, 74, 164-171.

(49) Theodossiou, T. A.; Noronha-Dutra, A.; Hothersall, J. S. Int. J. Biochem. Cell Biol. 2006, 38, $1946-1956$.

(50) Russell, M. A.; Morgan, N. G. Islets 2010, 2, 374-382. 
(51) Schrammel, A.; Behrends, S.; Schmidt, K.; Koesling, D.; Mayer, B. Mol. Pharmacol. 1996, $50,1-5$.

(52) Velingkar, V. S.; Gupta, G. L.; Hegde, N. B. Phytochem. Rev. 2017, 16, 725-744.

(53) Fernhoff, N.; Derbyshire, E.; Underbakke, E.; Marletta, M. J. Biol. Chem. 2012, 287, 43053-43062.

(54) Yoo, B. K.; Lamarre, I.; Martin, J. L.; Negrerie, M. J. Biol. Chem. 2012, 287, 6851-6859.

(55) Negrerie, M.; Bouzhir, L.; Martin, J.-L.; Liebl, U. J. Biol. Chem. 2001, 276, 46815-46821.

(56) Zhao, Y. D.; Brandish, P. E.; Di Valentin, M.; Schelvis, J. P. M.; Babcock, G. T.; Marletta, M. A. Biochemistry 2000, 39, 10848-10854.

(57) Rahaman, M. M.; Nguyen, A. T.; Miller, M. P.; Hahn, S. A.; Sparacino-Watkins, C.; Jobbagy, S.; Carew, N. T.; Cantu-Medellin, N.; Wood, K. C.; Baty, C. J.; Schopfer, F. J.; Kelley, E. E.; Gladwin, M. T.; Martin, E.; Straub, A. C. Circ. Res. 2017, 121, 137-148.

(58) Crosignani, S.; Bingham, P.; Bottemanne, P.; Cannelle, H.; Cauwenberghs, S.; Cordonnier, M.; Dalvie, D.; Deroose, F.; Feng, J. L.; Gomes, B.; Greasley, S.; Kaiser, S. E.; Kraus, M.; Négrerie, M.; Maegley, K.; Miller, N.; Murray, B. W.; Schneider, M.; Solowiej, J.; Stewart, A. E.; Tumang, J.; Torti, V.; Van den Eynde, B.; Wythes, M. J. Med. Chem. 2017, 60, 9617-9629.

(59) Stone, J. R.; Sands, R. H.; Dunham, W. R.; Marletta, M. A. Biochemistry 1996, 35, $3258-3262$.

(60) Fritz, B. G.; Hu, X. H.; Brailey, J. L.; Berry, R. E.; Walker, F. A.; Montfort, W. R. Biochemistry 2011, 50, 5813-5815.

(61) Huntosova, V.; Stroffekova, K. Cancers 2016, 8, 93.

(62) Galeotti, N.; Vivoli, E.; Bilia, A. R.; Vincieri, F. F.; Ghelardini, C. Biochem. Pharmacol. 2010, 79, 1327-1336.

(63) Fan, X.; Bai, J.; Zhao, S.; Hu, M.; Sun, Y.; Wang, B.; Ji, M.; Jin, J.; Wang, X.; Hu, J.; Li, Y. Toxicol. In Vitro 2019, 61, UNSP 104642.

(64) Tuna, G.; Kulaksı-Erkmen, G.; Dalmizrak, O.; Dogan, A.; Ogus, I. H.; Ozer, N. Chem. Biol. Interact. 2010, 188, 59-65.

(65) Kleber, E.; Obry, T.; Hippeli, S.; Schneider, W.; Elstner, E. F. Drug Res. 1999, 49, 106-109.

(66) Lavie, G.; Mandel, M.; Hazan, S.; Barliya, T.; Blank, M.; Grunbaum, A.; Meruelo, D.; Solomon, A. Angiogenesis 2005, 8, 35-42.

(67) Higuchi, A.; Yamada, H.; Yamada, E.; Jo, N.; Matsumura, M. Mol. Vis. 2008, 14, 249-254.

(68) Das, K.; Smirnov, A. V.; Wen, J.; Miskovsky, P.; Petrich, J. W. Photochem. Photobiol. 1999, 69, 633-645.

(69) Dang, L.; Seale, J. P.; Qu, X. Am. J. Chin. Med. 2007, 35, 713-723.

(70) Correche, E. R.; Enriz, R. D.; Piovano, M.; Garbarino, J.; Gomez-Lechon, M. J. Altern. Lab. Anim. 2004, 32, 605-615.

(71) Wassman, C. D.; Baronio, R.; Demir, Ö.; Wallentine, B. D.; Chen, C.-K.; Hall, L. V.; Salehi, F.; Lin, D.-W.; Chung, B. P.; Wesley Hatfield, G.; Richard Chamberlin, A.; Luecke, H.; Lathrop, R. H.; Kaiser, P.; Amaro, R. E. Nat. Commun. 2013, 4, 1407.

(72) McGillick, B. E.; Kumaran, D.; Vieni, C.; Swaminathan, S. Biochemistry 2016, 55, 1091-1099.

(73) Polonik, N. S.; Sabutskii, Y. E.; Polonik, S. G. Nat. Prod. Comm. 2018, 13, 1319-1322.

(74) Landry, D. W.; Oliver, J. A. New Engl. J. Med. 2001, 345, 588-595.

(75) Levy, B.; Fritz, C.; Tahon, E.; Jacquot, A.; Auchet, T.; Kimmoun, A. Crit. Care 2018, 22, 52.

(76) Stawicki, S. P.; Sims, C.; Sarani, B.; Grossman, M. D.; Gracias, V. H. Mini Rev. Med. Chem. 2008, 8, 472-490.

(77) Hosseinian, L.; Weiner, M.; Levin, M. A.; Fischer, G. W. Anesth. Analg. 2016, 122, 194-201.

(78) Levin, R. L.; Degrange, M. A.; Bruno, G. F.; Del Mazo, C. D.; Taborda, D. J.; Griotti, J. J.; Boullon, F. J. Ann. Thorac. Surg. 2004, 77, 496-499.

(79) Gruetter, C. A.; Kadowitz, P. J.; Ignarro, L. J. Can. J. Physiol. Pharmacol. 1981, 59, 150-156. 
(80) Mayer, B.; Brunner, F.; Schmidt, K. Biochem. Pharmacol. 1993, 45, 367-374.

(81) Lou, D.; Das, S.; Vincent, S. R. Eur. J. Phamacol. 1995, 290, 247-251.

(82) Feelisch, M.; Kotsonis, P.; Siebe, J.; Clement, B.; Schmidt, H. H. W. Mol. Pharmacol. 1999, $56,243-253$.

(83) Sammut, S.; Threlfell, S.; West, A. R. Neuropharmacology 2010, 58, 624-631.

(84) Bariotto-dos-Santos, K.; Padovan-Neto, F. E.; Bortolanza, M.; dos-Santos-Pereira, M.; Raisman-Vozari, R.; Tumas, V.; Del Bel, E. Eur. J. Neurosci. 2019, 49, 869-882.

(85) Kanao, T.; Sawada, T.; Davies, S.-A.; Ichinose, H.; Hasegawa, K.; Takahashi, R.; Hattori, N.; Imai, Y. PLOS One 2012, 7, e30958.

(86) Cai, Y.; Shen, H.; Zhan, J.; Lin, M.; Dai, L.; Ren, C.; Shi, Y.; Liu, J.; Gao, J.; Yang, Z. J. Am. Chem. Soc. 2017, 139, 2876-2879.

(87) Jain, A.; Jain, A.; Parajuli, P.; Mishra, V.; Ghoshal, G.; Singh, B.; Shivhare, U. S.; Katare, O. P.; Kesharwani, P. Drug Disc.Today 2018, 23, 960-973.

(88) Zhang, P.; Liu, G.; Chen, X. Nano Today 2017, 13, 7-9.

(89) Blanco, E.; Shen, H.; Ferrari, M. Nat. Biotechnol. 2015, 33, 941-951.

(90) Khalid, R. R.; Maryam, A.; Fadouloglou, V. E.; Siddiqi, A. R.; Zhang, Y. J. Mol. Graph. Model. 2019, 90, 109-119.

(91) Paprocka, M.; Krawczenko, A.; Dus, D.; Kantor, A.; Carreau, A.; Grillon C.; Kieda, C. Cytometry 2011, 79A, 594-602. 